\title{
Awareness among a Saudi Arabian university community of Middle East respiratory syndrome coronavirus following an outbreak
}

Maha Al-Mohaissen ${ }^{7}$

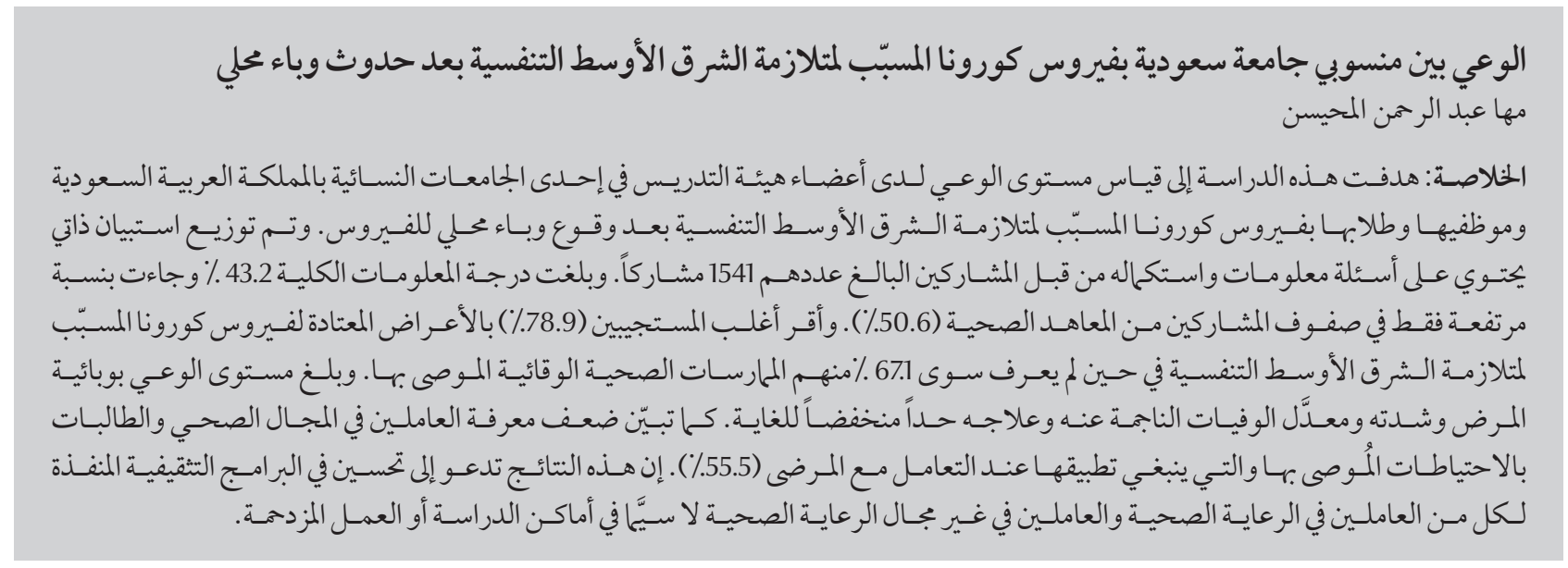

ABSTRACT This study aimed to measure the level of awareness of faculty members, staff and students in a female Saudi Arabian university community towards Middle East respiratory syndrome coronvirus (MERS-CoV) following an outbreak. A self-administered questionnaire containing knowledge questions was distributed and completed by the 1541 participants. The overall knowledge score was $43.2 \%$. It was only significantly higher in participants from the health colleges $(50.6 \%)$. The majority $(78.9 \%)$ of the respondents recognized the typical symptoms of MERS-CoV but only $67.1 \%$ knew the recommended preventive hygiene practices. Awareness of disease epidemiology, severity, fatality rate and treatment was very low. The knowledge of health care workers/ students of the recommended precautions that should be applied when dealing with patients was poor (55.5\%). Significant improvement in educational programmes for both the health care and non-health care professionals is warranted, particularly in crowded educational institutions or workplaces.

Sensibilisation d'une communauté universitaire saoudienne au coronavirus du syndrome respiratoire du Moyen-Orient après une flambée

RÉSUMÉ La présente étude avait pour objectif de mesurer le niveau de sensibilisation du corps enseignant et étudiant, et du personnel d'une communauté universitaire saoudienne composée de femmes à l'égard du coronavirus du syndrome respiratoire du Moyen-Orient (MERS-COV) après une flambée. Un auto-questionnaire comprenant des questions de connaissance a été distribué et rempli par 1541 participants. Le score général de connaissance était de 43,2 \% et n'était significativement plus élevé que chez les participants issus de facultés de santé $(50,6 \%)$. La majorité des répondants (78,9\%) était capable d'identifier les symptômes caractéristiques du MERS-COV, mais seulement 67,1\% connaissaient les pratiques d'hygiène préventives recommandées. La sensibilisation à l'égard de l'épidémiologie, de la gravité, des taux de létalité et du traitement de la maladie était très basse. La connaissance des agents de santé et des étudiants en soins de santé portant sur les précautions recommandées qui devraient être appliquées lors de la prise en charge de patients était faible (55,5\%). Une amélioration significative des programmes de formation mis en œuvre à la fois pour les professionnels des soins et les professionnels extérieurs au milieu de la santé est requise, en particulier dans les lieux d'étude ou les environnements de travail avec une forte concentration de personnes. 


\section{Introduction}

Middle East respiratory syndrome coronavirus (MERS-CoV) was first identified in 2012 in Saudi Arabia (1). Since then cases have been reported worldwide. The syndrome comprises a viral respiratory illness which ranges in clinical presentation from a mild upper respiratory illness to rapidly progressive pneumonia and multi-organ failure. The largest outbreaks have been linked to overcrowding, delay in diagnosis and poor infection control practices. Chains of transmission can be interrupted by the implementation of control measures (2).

Awareness among the SaudiArabian community of this infection has not been well established. Available studies are few and are limited by the small number of participants (3), reporting on participants' personal practices rather than the individual's adherence to the current recommendations, and evaluating only minor aspects of public knowledge (3-5). In general, there is a lack of studies on the awareness and attitude of the Saudi Arabian public towards infectious diseases. Public awareness of infectious diseases aids significantly in infection control whereas a lack of reasonable knowledge leads to low detection rates, delayed treatment, discrimination and stigma (6).

It is important to assess the knowledge, attitudes and behaviour of the public towards important and prevalent infectious diseases. Such information provides baseline data for the prevention and control of these diseases through estimation of the impact of previous prevention efforts made by the government and guiding the need for further interventions (6). Additionally, measuring the awareness of the public is valuable during an outbreak as appropriate public response during an outbreak is governed by the public's understanding of disease transmission, availability of vaccines and effective medical treatment (7).
Furthermore, the information obtained would be crucial to improving the communication efforts of public health officials and clinicians among the population at risk (8). Appropriate changes in public behaviour in response to an outbreak can alter the progression of the infectious agent (9).

The spread of infection in close contact environments, including crowded work or study places, can be hazardous and a high level of knowledge, particularly on preventive strategies, is paramount. Recently an outbreak occurred at Princess Nourah bint Abdulrahman University, the world's largest all-female university: 4 cases of MERS-CoV infection were detected among the janitors (10). The 4 workers were quarantined and no MERS-CoV cases were reported amongst the students (11). The present study was designed to measure the awareness of MERS-CoV infection among the students, faculty members and other employees at the university following the outbreak.

\section{Methods}

\section{Population}

This prospective cross-sectional study was conducted between 10 December 2015 and 10 February 2016 at the all-female Princess Nourah bint Abdulrahman University. Students, faculty members and non-academic staff were invited to participate in the study. A previous study indicated that about $54 \%$ of the Saudi Arabian public had a good knowledge regarding MERS-CoV infection (5). With a margin of error of $5 \%$, level of confidence of $95 \%$ and power of study of $80 \%$, the minimum sample size required was calculated to be 606 . As we used a convenience sample of participants (not randomized), the actual sample was much larger to minimize selection bias

\section{Questionnaire and data collection}

A questionnaire was developed using the frequently asked questions posted on the World Health Organization (WHO) and the Saudi Arabian Ministry of Health websites (12,13). The questions and their correct responses are available on the websites both in Arabic and in English. The Arabic version was used to ensure better understanding among the participants. The term MERS-CoV in the original questions was replaced by "corona infection" as this is the term commonly used to refer to the syndrome in the local community. One question was developed in English and translated to Arabic using a published reference (2). The final questionnaire was reviewed for face validity by the expert panel of the research centre at the college of medicine and was pilot tested on 20 subjects from the target population, who were not included in the study. It was modified as necessary. Cronbach's alpha was calculated to be 0.7 .

The questionnaire contained questions on participants' demographic data, including age, level of education, occupation and college. There were 20 multiple choice knowledge questions that tested the following knowledge aspects in relation to MERS-CoV infection: disease epidemiology (3 questions); symptoms and incubation period (3 questions); possible infection sources, mode of transmission, and common places for outbreaks (6 questions), precautions and preventive strategies (4 questions); treatment and fatality rate (2 questions); and infection in special patient populations, including children and medically compromised individuals (2 questions). An additional question was addressed only to health care workers, including students or academic staff from the colleges of nursing, medicine, dentistry, pharmacy and health and rehabilitation sciences who were in contact with patients. This question was analysed separately. 
The questions had 1 correct answer, 3 incorrect answers and a "don't know" option.

The study followed the principles of the Helsinki Declaration and ethics approval was obtained from our institutional review board before data acquisition. The questionnaire was distributed by 2 research coordinators. A convenience sample was taken. Completion was voluntary and anonymous. Consent was verbal and implied by the participant completion and returning the questionnaire.

\section{Statistical analysis}

Data were analysed using $S A S$, version 9.4. Only complete questionnaires were included in the analysis. The results of the knowledge questions were analysed using the answer key. The knowledge score for the whole sample was expressed as the percentage of correct answers of the 20 questions in the questionnaire. The last question was analysed only for participants from the 5 health colleges. Categorical variables are reported as number and percentage, and continuous variables are expressed as mean and standard deviation (SD). Comparison of scores between groups was based on analysis of variance, Kruskal-Wallis test, chi-squared test or Fisher's exact test, as appropriate. The Bonferroni correction was applied to $\mathrm{P}$-values obtained from pairwise comparisons between groups. P-value $\leq 0.05$ was considered statistically significant.

\section{Results}

\section{Demographic characteristics of the study population}

A total of 1541 questionnaires were complete and were included in the study; 91 were returned incomplete and were excluded from the analysis. The demographic data of the study participants are summarized in Table
1. The mean age of the respondents was 23 (SD 5.8) years ( $80.6 \%$ were $<24$ years old). The majority of the participants were students (82\%).

\section{Knowledge scores of the participants}

The overall knowledge score was $43.2 \%$. The scores of the assessed knowledge aspects were as follows: epidemiology (53.3\%), symptoms recognition (45.5\%), sources and mode of transmission (43.5\%), precautions (43.2\%), treatment and fatality rate (28.5\%) and infection in special populations (38.4\%) (Table 2).

\section{Awareness of MERS-CoV symptoms, contagiousness and fatality rate}

The responses to the knowledge questions are displayed in Table 3. The majority of the respondents (76.8\%) were aware that MERS-CoV comprises a viral respiratory illness, and $78.9 \%$ correctly identified its typical symptoms. Most of the participants overestimated the contagiousness and fatality rate of MERS-CoV. 53.3\% of the participants thought that the infection was highly contagious, and $22 \%$ thought it was moderately contagious. Only $14.3 \%$ correctly responded that it is contagious to a limited degree. $3.6 \%$ considered the syndrome non-contagious. $66.1 \%$ of the respondents exaggerated the infection fatality rate $(6.6 \%$ considered the disease fatal in all cases, $31.3 \%$ thought it is fatal in $75 \%$ of the cases and $28.2 \%$ believed it was fatal in $50 \%$ of the cases.

\section{Knowledge of precaution measures and travel recommendations}

Around two thirds of the participants knew the recommended general infection control precautions (Table 3); 7.6\% thought that the latest medical consensus advice was not to touch surfaces and objects directly, $8.4 \%$ believed that they should wear a mask when leaving their home and 6.0\% thought they should take antibiotics daily to avoid getting infected. Among the health care workers, only $55.3 \%$ correctly identified the precautions that should be applied when dealing with

Table 1 Demographic characteristics of the study participants $(n=1541)$, Riyadh, Saudi Arabia, 2016

\begin{tabular}{lcc} 
Characteristic & $23 \pm(5.8)$ \\
Age $($ mean $\pm S D$ ) years & No. & $\%$ \\
Level of education & 14 & 0.9 \\
Less than high school & 1145 & 74.3 \\
High school & 313 & 20.3 \\
Bachelor degree & 35 & 2.3 \\
Masters degree & 34 & 2.2 \\
PhD or board certified & & \\
College & 375 & 24.3 \\
Humanities and community colleges & 458 & 29.7 \\
Science colleges & 510 & 33.1 \\
Health colleges & 198 & 12.8 \\
Nonspecific* and preparatory year students & & \\
Occupation & 1264 & 82.0 \\
Student & 210 & 13.6 \\
Non-academic staff & 67 & 4.3 \\
Faculty member & & \\
\hline
\end{tabular}

*Includes employees in the associate deanships, office workers, security personnel and janitors. 
patients to prevent the transmission of infection (Table 3).

Regarding travel recommendations, $30.8 \%$ thought that the WHO recommends screening of all travellers arriving from countries that have reported MERS-CoV cases and only $18.0 \%$ knew that the WHO does not recommend travel restrictions for MERS-CoV (Table 3); 7.8\% thought that the WHO advises some travellers to cancel Hajj and Umrah travel plans due to concerns regarding MERS$\mathrm{CoV}$ and $7.5 \%$ believed that the WHO prohibits travellers from Saudi Arabia from entering certain countries.

\section{Factors associated with knowledge of MERS-CoV}

Table 4 shows the correlation between the participants' occupation and knowledge score. There was no significant difference in the total mean knowledgescorebetween students, nonacademic staff and faculty members, (43.3\% (SD 15.0), 41.8\% (SD 16.7) and $46.4 \%$ (SD 20.3) respectively, $(P$ $=0.104$ ) although significant variability in some knowledge aspects was noted. The students had better knowledge of MERS-CoV symptoms and incubation period than the non-academic staff (Table 4) while the faculty members had better knowledge regarding treatment and fatality rate compared with both students and non-academic staff: $44.0 \%$ (SD 36.4), 28.2\% (SD 33.1 ), and 25.7\% (SD 30.2) respectively $(P<0.001)$. There was no significant difference in regard to knowledge of the recommended precautionary measures against MERS-CoV infection, including the recommended daily precautions ( $P$ $=0.376$ ).

Table 5 shows the correlation between MERS-CoV knowledge scores and the participants' college. Participants from the health colleges had significantly better awareness in all tested knowledge aspects with a total score of $50.6 \%$ compared with $40.8 \%, 38.2 \%$ and $39.4 \%$ for the science,

\begin{tabular}{lcc}
\hline \multicolumn{2}{l}{ Table 2 Knowledge scores of the participants $(\boldsymbol{n}=\mathbf{1 5 4 1})$, Riyadh, Saudi Arabia, 2016 } \\
\hline Item & \multicolumn{2}{c}{ Total score } \\
& Mean & SD \\
Total & 43.2 & 15.5 \\
Epidemiology & 53.3 & 27.1 \\
Symptoms and incubation period & 45.5 & 26.2 \\
Infection sources, mode of transmission and common & 43.5 & 20.8 \\
places for outbreaks & & \\
Precautions and preventive strategies & 43.2 & 26.9 \\
Treatment and fatality rate & 28.5 & 33.1 \\
Infection in special populations & 38.4 & 33.9 \\
\hline
\end{tabular}

$S D=$ standard deviation .

humanities/community colleges and non-specific college/preparatory year students respectively $(\mathrm{P}<0.001)$. Participants from the science colleges had slightly better scores compared with their counterparts from the humanities and community colleges $[40.8 \%$ (SD 15.1 ) versus $38.2 \%$ (SD 13.3), $P=$ $0.028]$, however this was mainly due to better knowledge of the epidemiology of the infection.

Table 6 details the impact of the participant's education level on their knowledge score. Participants with less than high school education had the lowest knowledge scores (27.5\%) compared with the other participants [completed high school (43.2\%), bachelor's degree (44.3\%), masters' degree (43.4\%), PhD or board certified $(40.3 \%)(P=0.002)]$. Participants with less than high school education had the lowest knowledge scores for symptoms and incubation period of MERS-CoV, $11.9 \%$ (SD 16.6), compared with the other groups $(P<0.001)$.

When analysed by age, no significant difference was noted in the total scores of participants (Spearman correlation coefficient $=0.04)$. When participants aged $<24$ years were compared with those $\geq 24$ years, there was little difference in the total knowledge scores, $43.2 \%$ (SD 15.1) versus $43.1 \%$ (SD 17.2) $(P=0.185)$. The younger participants were, however, more aware of MERS-CoV symptoms and incubation period, $46.6 \%$ (SD 25.7) versus
40.9\% (SD 27.8) $(P=0.001)$, whereas the older participants had better knowledge of infection in special populations, 44.1\% (SD 37.2) versus 37.0\% (SD 32.9) $P=0.004)$ (data not shown).

\section{Discussion}

This is the largest study to date on the awareness of MERS-CoV infection in Saudi Arabia. This study shows that the awareness of a sample of a Saudi Arabian university community regarding MERS-CoV infection following a recent outbreak is very poor. Knowledge of disease symptoms and recommended daily protective measures was relatively better, but remained suboptimal. The understanding of potential infection sources, fatality rate, treatment and WHO travel recommendations was deficient. Most of the respondents had a very low level of knowledge and some misconceptions were detected. The results also demonstrate that, although some variability was noted in knowledge about certain aspects of MERS-CoV between the groups, the total knowledge scores were similar. The total knowledge score was not affected by level of education (with the exception of in those with less than high school education) or age and was not significantly different between students, faculty members and non-academic staff. Only the college type significantly affected the total knowledge score, 


\begin{tabular}{|c|c|c|c|}
\hline \multirow[t]{2}{*}{ Question } & \multirow[t]{2}{*}{ Correct answer } & \multicolumn{2}{|c|}{ Accurate responses } \\
\hline & & No. & $\%$ \\
\hline $\begin{array}{l}\text { What is Middle East respiratory syndrome } \\
\text { "corona infection"? }\end{array}$ & $\begin{array}{l}\text { A viral respiratory illness caused by a corona } \\
\text { virus. }\end{array}$ & 1184 & 76.8 \\
\hline $\begin{array}{l}\text { When and where, corona infection was first } \\
\text { identified? }\end{array}$ & In 2012, in Saudi Arabia. & 602 & 39.1 \\
\hline $\begin{array}{l}\text { How spread out is corona infection throughout } \\
\text { the world? }\end{array}$ & $\begin{array}{l}\text { It has been reported in multiple countries } \\
\text { worldwide. }\end{array}$ & 679 & 44.1 \\
\hline How severe is the infection by corona? & $\begin{array}{l}\text { It is variable ranging from mild to severe } \\
\text { disease. Some infected individuals may be } \\
\text { asymptomatic. }\end{array}$ & 582 & 37.8 \\
\hline $\begin{array}{l}\text { What are the typical symptoms of corona } \\
\text { infection? }\end{array}$ & $\begin{array}{l}\text { Fever, cough, difficulty in respiration and } \\
\text { occasionally diarrhoea. }\end{array}$ & 1216 & 78.9 \\
\hline $\begin{array}{l}\text { What is the incubation period (time from } \\
\text { infection to symptom onset)? }\end{array}$ & The average is 5 days ( $2-14$ days) & 307 & 19.9 \\
\hline Is infection by corona contagious? & Yes to a limited degree. & 221 & 14.3 \\
\hline $\begin{array}{l}\text { If you think corona infection is contagious, } \\
\text { what are the potential routes of infection } \\
\text { transmission? }\end{array}$ & $\begin{array}{l}\text { Animals, infected family members and from } \\
\text { patients to health care professionals. }\end{array}$ & 932 & 60.5 \\
\hline $\begin{array}{l}\text { In your opinion where do infected cases } \\
\text { cluster most? }\end{array}$ & In the health care setting. & 710 & 46.1 \\
\hline How do people get infected with corona? & $\begin{array}{l}\text { It is not yet fully understood how people } \\
\text { become infected with corona. }\end{array}$ & 182 & 11. 8 \\
\hline What is the source of infection by corona? & Camels & 1120 & 72.7 \\
\hline $\begin{array}{l}\text { What are the common causes for spread of } \\
\text { infection by corona? }\end{array}$ & $\begin{array}{l}\text { Overcrowding, delay in diagnosis and poor } \\
\text { infection control practices. }\end{array}$ & 854 & 55.4 \\
\hline $\begin{array}{l}\text { What precautions should be taken to avoid } \\
\text { getting infected by corona? }\end{array}$ & $\begin{array}{l}\text { According to the latest medical consensus, it } \\
\text { is advised to wash hands with water and soap } \\
\text { or with other disinfectants, especially after } \\
\text { coughing, sneezing and using toilets. Use a } \\
\text { handkerchief when coughing or sneezing to } \\
\text { cover your mouth and nose. Avoid touching } \\
\text { your mouth, nose and eyes before washing your } \\
\text { hands and avoid eating raw meat, liver and raw } \\
\text { or unpasteurized milk. }\end{array}$ & 1034 & 67.1 \\
\hline $\begin{array}{l}\text { Is it safe to consume raw or insufficiently } \\
\text { cooked animal products, including dairy } \\
\text { products and meat? }\end{array}$ & $\begin{array}{l}\text { Camel meat and camel milk are nutritious } \\
\text { products that one can continue to consume after } \\
\text { pasteurization, cooking or other heat treatments. }\end{array}$ & 449 & 29.1 \\
\hline Is it safe to visit farms, markets, or camel fairs? & $\begin{array}{l}\text { Yes: with precautions, including regular hand- } \\
\text { washing before and after touching animals and } \\
\text { avoiding contact with sick animals. }\end{array}$ & 904 & 58.7 \\
\hline $\begin{array}{l}\text { Does the WHO impose restrictions on travel or } \\
\text { trade due to corona infection? }\end{array}$ & $\begin{array}{l}\text { The WHO does not recommend travel or trade } \\
\text { restrictions with regard to corona infection. }\end{array}$ & 278 & 18.0 \\
\hline $\begin{array}{l}\text { Is there a vaccine against corona infection? } \\
\text { What is the treatment? }\end{array}$ & $\begin{array}{l}\text { There are is no vaccines and no specific } \\
\text { treatment available. Treatment is supportive. }\end{array}$ & 491 & 31.9 \\
\hline What is the fatality rate of corona infection? & The infection is fatal in $35 \%$ of the cases. & 388 & 25.2 \\
\hline Which groups are likely to have severe disease? & $\begin{array}{l}\text { Patients with diabetes, renal failure, chronic lung } \\
\text { disease and immunodeficiency. }\end{array}$ & 866 & 56.2 \\
\hline Regarding corona infection in children ... & $\begin{array}{l}\text { They are less likely get the infection compared } \\
\text { with adults. }\end{array}$ & 317 & 20.6 \\
\hline $\begin{array}{l}\text { What precautions should health care } \\
\text { professional take to prevent the transmission of } \\
\text { corona infection when dealing with patients? }\end{array}$ & $\begin{array}{l}\text { Universal precautions should be applied with } \\
\text { all patients. In confirmed or suspected cases, } \\
\text { respiratory precautions, eye protection and } \\
\text { special precautions for aerosol-generating } \\
\text { procedures should be added. }\end{array}$ & 282 & $55.3^{*}$ \\
\hline
\end{tabular}

*Result for participants from the health colleges only. 





which was higher among members of the health colleges.

Additionally, this study measured the participants' awareness towards disease aspects that are scientifically valid yet within public reach and knowledge level. The study explored new knowledge aspects, including disease epidemiology, infection sources, treatment and fatality rate, and used the WHO and Ministry of Health recommendations as the reference standard to gauge proper infection control practices. Our results are in accordance with previous studies. However, in addition to testing more knowledge aspects, we used a multiple choice question format rather than a true/false format, which may have posed some difficulty to the participants and this may explain the overall lower knowledge score observed in our sample (43.2\%) compared with the findings of Al-Mohrej et al. (54\%) (5).

Previous studies evaluating the awareness of the Saudi Arabian public towards MERS-CoV infection are limited (3-5). A study involving 1147 adult subjects in Riyadh reported a low level of knowledge of MERS-CoV incubation period, period of communicability and availability of vaccine, but a high level of knowledge on hygienic practices (4). Similar findings were reported in a study involving 1149 residents of Riyadh (5). That study, however, reported on the personal practices and precautions of the participants towards MERS-CoV rather than their awareness of the precautions recommended by health care authorities.

In another smaller study involving 200 dental students in Jeddah, 54\% of the participants had a good level of knowledge regarding the etiology, symptoms, and treatment of MERS$\mathrm{CoV}$, and $79 \%$ were aware of the infection control and protection measures. Our findings are in agreement with these results, and similar to our study, the authors used the WHO recommendations as a reference standard for proper participant awareness and practices (3).

The good level of knowledge of proper hygienic practices observed in our sample and in other studies (3-5) is reassuring but remains suboptimal. Saudi Arabian communities still lack awareness of recommended protective measures that help prevent the transmission of the virus (14). It is estimated that 44951 individuals older than 15 years may be seropositive for MERS-CoV in Saudi Arabia, and may be a source of infection for patients who have not been exposed to camels previously (15). A positive correlation has been demonstrated between contact with infected persons and infection risk, i.e. contacts are most in need of education on MERS-CoV to avoid spread of infection (14). Precautionary activities are therefore of great importance in avoiding infection and should be strengthened.

Health care workers/students, on the other hand, had poor knowledge of the recommended infection control precautions in the health care setting. This observation has important clinical implications as it may explain the high incidence of outbreaks and clustering of cases observed in the medical field. Our results on the health care workers/ students' awareness are in accordance with those reported previously by AlGhamdi et al. who reported a very low level of awareness (32.9\%) regarding the preventive measures against influenza A (H1N1) among health care workers during Hajj (16). They found that health care workers (especially non-physicians, those with fewer years of experience and those who were not aware of the guidelines) had difficulties in some preventive measures and highlighted the importance of training courses (16).

One of the early reports on MERSCoVinfection in Saudi Arabia described mild or asymptomatic infection in 7 health care workers who did not follow proper infection control procedures in patient care. The workers had no previous contact with animals (17). The close proximity of health care workers to patients and the handling of human biologic material (sputum, respiratory secretions, etc.) likely increase their infection risk and consequently infection transmission in hospitals (17). Our results suggest that the lack of proper hygiene practices may be primarily due to poor awareness rather than noncompliance.

There are limited data on public awareness of infectious diseases in Saudi Arabia. The available studies, however, are consistent in reporting low knowledge level and poor adoption of protective measures $(7,18-20)$. In a study on the awareness of the Saudi Arabian public towards H1N1 infection, $43.7 \%$ of the studied population were reported to have low knowledge level, and 60.8\% had taken no or minimal precautionary measures (7). Potential explanations for the poor awareness include the lacking of proper health education among the Saudi Arabian people (21) and people's neglect of Ministry of Health recommendations (7).

Following the outbreak at the university, awareness programmes were implemented (10) and educational posters and banners were distributed on campus. Our results, however, indicate that these measures may be inadequate. The Saudi Arabian public commonly derive their information from the internet, but physicians and other health care providers are considered the preferred source of information (14). Live lectures provided by physicians or other health care providers may, therefore, be more influential and have a greater impact on public knowledge. Frequent communication between physicians and the public helps dispel myths about the disease and clarifies the role that the public can play in limiting disease $\operatorname{spread}(7)$.

The Ministry of Health has implemented a series of preventive measures to limit the spread of MERS-CoV, 


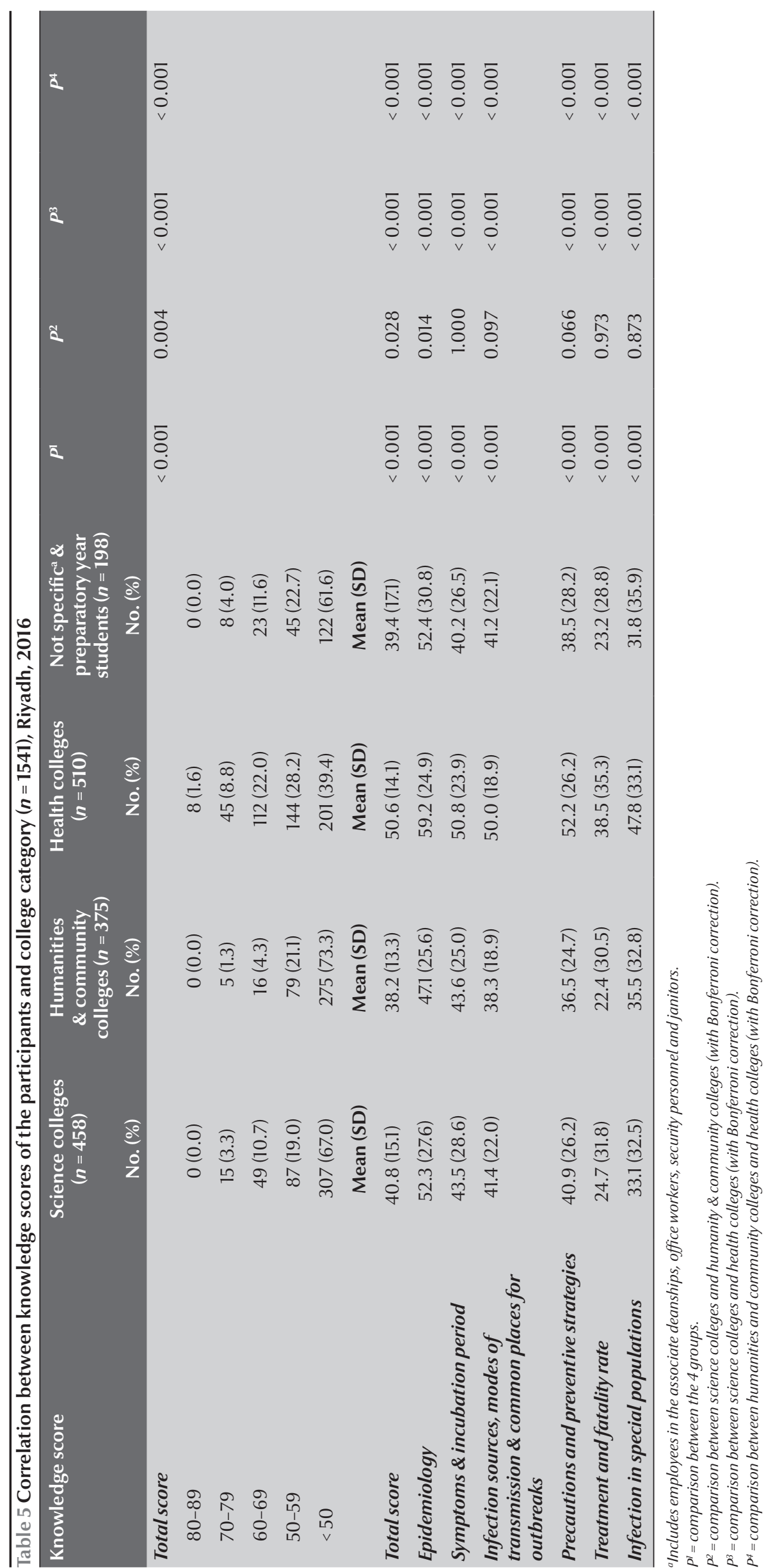




\begin{tabular}{|c|c|c|c|c|c|c|c|c|c|c|c|c|c|}
\hline \multirow[t]{2}{*}{ Knowledge } & \multicolumn{2}{|c|}{ All $(n=1541)$} & \multicolumn{2}{|c|}{$\begin{array}{l}\text { Less than high } \\
\text { school }\end{array}$} & \multicolumn{2}{|c|}{ High school } & \multicolumn{2}{|c|}{$\begin{array}{l}\text { Bachelor's } \\
\text { degree }\end{array}$} & \multicolumn{2}{|c|}{$\begin{array}{l}\text { Master's } \\
\text { degree }\end{array}$} & \multicolumn{2}{|c|}{$\begin{array}{l}\text { PhD or board } \\
\text { certified }\end{array}$} & \multirow[t]{2}{*}{$P$} \\
\hline & No. & $\%$ & No. & $\%$ & No. & $\%$ & No. & $\%$ & No. & $\%$ & No. & $\%$ & \\
\hline Score & & & & & & & & & & & & & 0.269 \\
\hline $80-89$ & 8 & 0.5 & 0 & 0.0 & 3 & 0.3 & 4 & 1.3 & 0 & 0.0 & 1 & 2.9 & \\
\hline $70-79$ & 73 & 4.7 & 0 & 0.0 & 57 & 5.0 & 12 & 3.8 & 1 & 2. 9 & 3 & 8.8 & \\
\hline $60-69$ & 200 & 13. 0 & 1 & 7.1 & 155 & 13.5 & 35 & 11. 2 & 5 & 14.3 & 4 & 11.8 & \\
\hline $50-59$ & 355 & 23.0 & 2 & 14.3 & 255 & 22.3 & 82 & 26.2 & 11 & 31. 4 & 5 & 14.7 & \\
\hline \multirow[t]{2}{*}{$<50$} & 905 & 58.7 & 11 & 78.6 & 675 & 59.0 & 180 & 57.5 & 18 & 51.4 & 21 & 61.8 & \\
\hline & Mean & SD & Mean & SD & Mean & SD & Mean & SD & Mean & SD & Mean & SD & \\
\hline Total score & 43.2 & 15.5 & 27.5 & 19. 2 & 43.2 & $15.6^{*}$ & 44.3 & $13.9^{*}$ & 43.4 & $15.2^{*}$ & 40.3 & $20.8^{*}$ & 0.002 \\
\hline Epidemiology & 53.3 & 27.1 & 42.9 & 38.0 & 53.1 & 27.1 & 54.5 & 26.2 & 55.2 & 29.1 & 51.0 & 28.7 & 0.783 \\
\hline $\begin{array}{l}\text { Symptoms \& } \\
\text { incubation } \\
\text { period }\end{array}$ & 45.5 & 26.2 & 11.9 & 16.6 & 45.4 & 25.9 & 47.6 & 26.2 & 45.7 & 23.0 & 45.1 & 33.7 & $<0.001$ \\
\hline $\begin{array}{l}\text { Infection } \\
\text { sources, } \\
\text { mode of } \\
\text { transmission } \\
\text { \& common } \\
\text { places for } \\
\text { outbreaks }\end{array}$ & 43.5 & 20.8 & 32.1 & 21.1 & 43.7 & 20.9 & 44.4 & 20.2 & 39.0 & 22.1 & 36.3 & 21.1 & 0.045 \\
\hline $\begin{array}{l}\text { Precautions } \\
\text { \& preventive } \\
\text { strategies }\end{array}$ & 43.2 & 26.9 & 25.0 & 31.0 & 42.8 & 26.7 & 45.6 & 26.8 & 42.9 & 25.4 & 43.4 & 29.7 & 0.058 \\
\hline $\begin{array}{l}\text { Treatment \& } \\
\text { fatality rate }\end{array}$ & 28.5 & 33.1 & 14.3 & 23.4 & 29.0 & 33.3 & 26.8 & 32.3 & 32.9 & 36.3 & 29.4 & 30.4 & 0.413 \\
\hline $\begin{array}{l}\text { Infection } \\
\text { in special } \\
\text { populations }\end{array}$ & 38.4 & 33.9 & 32.1 & 37.2 & 38.1 & 33.6 & 39.1 & 33.6 & 47.1 & 41.9 & 33.8 & 36.3 & 0.535 \\
\hline
\end{tabular}

$P=0.424$ for comparison between the 4 groups.

including organizing conferences, holding meetings and television interviews in addition to issuing press releases on a regular basis and using text messages sent via mobile phones to update the public on new developments (5). It is not clear however if these messages are reaching the general population and increasing their awareness (14) and evaluation of these educational methods should be performed. Raising public awareness should be achieved through scientific health education and without creating anxiety and fear in the community, which might increase anxiety and demands on health services unnecessarily (22). A policy that shifts the emphasis from detection and outbreak response to prevention of infection at source is recommended and is expected to result in better protection of animal and human health and the economy (23).

Raising the level of knowledge of infectious diseases not only helps the general population protect themselves, but also encourages those suspected of being infected to seek medical help early and be treated more completely (24). Evidence suggests that educational intervention through educational leaflets, group and individual discussions, visual show and lectures is associated with improvement in the knowledge scores on infectious disease in the Saudi Arabian community as well as attitudes and practices (18). This can be provided in colleges, schools and work places. The media and the Internet are also considered important sources of information in the Saudi Arabian community $(3,14)$ and can be used to target a wider sector of the community, including those at home. It should be emphasized that it is important to raise awareness among both the medical community and the general public to eliminate the factors that contribute to infection outbreaks (25).

There are some limitations to this study including the fact that it represents the knowledge of Saudi Arabian females only. Nonetheless, some of the results obtained in this study are similar to those reported previously in the community. Previous studies have shown that females scored significantly better than their male counterparts in questions related to protective measures (5) and that while sex was a significant 
predictor of the level of concern, it did not predict precaution. Subject knowledge, on the other hand, predicted both concern and precaution (4). Additionally, although this study represents the knowledge of a university community, the majority of the respondents were university students with high school education and therefore the level of education of the participants was not higher than that of participants from the community in previous studies $(4,5)$. The low knowledge scores observed in our sample may also reflect the diversity of the questions and knowledge aspects tested.

Our findings emphasize the low public awareness of preventive measures for infectious diseases, and may serve as a reference point to guide future education programmes.

\section{Acknowledgement}

The author would like to thank Dr Terry Lee from the Centre for Health Evaluation and Outcome Sciences for his excellent help with the data analysis for this study.

Funding: None.

Competing interests: None declared.

\section{References}

1. Zaki AM, van Boheemen S, Bestebroer TM, Osterhaus AD, Fouchier RA. Isolation of a novel coronavirus from a man with pneumonia in Saudi Arabia. N Eng J Med. 2012;367(19):181420. PMID:23075143

2. Omrani AS, Shalhoub S. Middle East respiratory syndrome coronavirus (MERS-CoV): what lessons can we learn? J Hosp Infect. 2015;91(3):188-96. PMID:26452615

3. Kharma MY, Alalwani MS, Amer MF, Tarakji B, Aws G. Assessment of the awareness level of dental students toward Middle East Respiratory Syndrome-coronavirus. J Int Soc Prev Community Dent. 2015;5(3):163-9. PMID:26236674

4. Almutairi KM, Al Helih EM, Moussa M, Boshaiqah AE, Saleh Alajilan A, Vinluan JM, et al. Awareness, Attitudes, and Practices Related to Coronavirus Pandemic Among Public in Saudi Arabia. Fam Community Health. 2015;38(4):332-40. PMID:26291193

5. Al-Mohrej OA, Al-Shirian SD, Al-Otaibi SK, Tamim HM, Masuadi EM, Fakhoury HM. Is the Saudi public aware of Middle East respiratory syndrome? J Infect Public Health. 2015;9(3):259-66. PMID:26589657

6. Liu H, Li M, Jin M, Jing F, Wang H, Chen K. Public awareness of three major infectious diseases in rural Zhejiang province, China: a cross-sectional study. BMC Infect Dis. 2013;13:192. PMID:23627258

7. Balkhy HH, Abolfotouh MA, Al-Hathlool RH, Al-Jumah MA. Awareness, attitudes, and practices related to the swine influenza pandemic among the Saudi public. BMC Infect Dis. 2010;10:42. PMID:20187976

8. Abraham T. Lessons from the pandemic: the need for new tools for risk and outbreak communication. Emerg Health Threats J. 2011;4:7160. PMID:24149033

9. Funk S, Gilad E, Watkins C, Jansen VA. The spread of awareness and its impact on epidemic outbreaks. Proc Natl Acad Sci U S A. 2009;106:6872-7. PMID:19332788

10. Stirling BV, Harmston J, Alsobayel H. An educational programme for nursing college staff and students during a MERScoronavirus outbreak in Saudi Arabia. BMC Nurs. 2015;14:20. PMID:25904821

11. 4 Workers at PNU quarantined, no MERS-CoV cases reported amongst students. Riyadh: Ministry of Health; 2015 (http:// www.moh.gov.sa/en/Ministry/MediaCenter/News/Pages/ news-2015-10-15-002.aspx, accessed 22 February 2017).

12. FAQs Coronavirus (MERS-CoV). Riyadh: Ministry of Health; 2014 (http://www.moh.gov.sa/en/CCC/FAQs/Corona/Pages/default.aspx, accessed 22 February 2017).

13. Frequently asked questions on Middle East respiratory syndrome coronavirus (MERS-CoV). Geneva: World Health
Organization; 2015 (http://www.who.int/csr/disease/coronavirus_infections/faq/en/, accessed 22 February 2017).

14. Hoda J. Identification of information types and sources by the public for promoting awareness of Middle East respiratory syndrome coronavirus in Saudi Arabia. Health Educ Res. 2016 Feb;31(1):12-23. PMID:26612051

15. Muller MA, Meyer B, Corman VM, Al-Masri M, Turkestani A, Ritz D, et al. Presence of Middle East respiratory syndrome coronavirus antibodies in Saudi Arabia: a nationwide, crosssectional, serological study. Lancet Infect Dis. 2015;15(5):629.

16. Al-Ghamdi AS, Kabbash IA. Awareness of healthcare workers regarding preventive measures of communicable diseases among Hajj pilgrims at the entry point in Western Saudi Arabia. Saudi Med J. 2011;32(11):1161-7. PMID:22057605

17. Memish ZA, Zumla Al, Assiri A. Middle East respiratory syndrome coronavirus infections in health care workers. N Eng J Med. 2013;369(9):884-6. PMID:23923992

18. Al-Thaqafy MS, Balkhy HH, Memish Z, Makhdom YM, Ibrahim A, Al-Amri A, et al. Improvement of the low knowledge, attitude and practice of hepatitis $B$ virus infection among Saudi national guard personnel after educational intervention. BMC Res Notes. 2012;5:597. PMID:23111118

19. Fageeh WM. Sexual behavior and knowledge of human immunodeficiency virus/aids and sexually transmitted infections among women inmates of Briman Prison, Jeddah, Saudi Arabia. BMC Infect Dis. 2014;14:290. PMID:24884734

20. AlObaid A, Al-Badawi IA, Al-Kadri H, Gopala K, Kandeil W, Quint W, et al. Human papillomavirus prevalence and type distribution among women attending routine gynecological examinations in Saudi Arabia. BMC Infect Dis. 2014;14:643. PMID:25496614

21. Aziz AT, Salman AA. Re: Prevention is better than cure for emerging infectious diseases. BMJ 2014;348:g1499.

22. Al Turki YA. Can we increase public awareness without creating anxiety about corona viruses? Patient Educ Couns. 2014;94(2):286-7. PMID:24284163

23. Heymann DL, Dar OA. Prevention is better than cure for emerging infectious diseases. BMJ. 2014;348:g1499. PMID:24563451

24. Lu SH, Tian BC, Kang XP, Zhang W, Meng XP, Zhang JB, et al. Public awareness of tuberculosis in China: a national survey of 69253 subjects. Int J Tuberc Lung Dis. 2009;13(12):1493-9. PMID:19919766

25. Chang SC. Raising clinical awareness for better dengue fever outbreak control. J Formos Med Assoc. 2015;114(11):1025-6. PMID:26585886 